\title{
Lashed by the wind: short-term Middle Palaeolithic occupations within the loess-palaeosoil sequence at Monte Netto (Northern Italy)
}

\author{
Davide Delpiano $^{\mathrm{a}}$, Marco Peresani ${ }^{\mathrm{a}, *}$, Stefano Bertola ${ }^{\mathrm{a}}$, Mauro Cremaschi ${ }^{\mathrm{b}}$, Andrea Zerboni $^{\mathrm{b}}$ \\ ${ }^{a}$ Università di Ferrara, Dipartimento di Studi Umanistici, Sezione di Scienze Preistoriche e Antropologiche, Ferrara, Italy \\ b Università degli Studi di Milano, Dipartimento di Scienze della Terra "A. Desio", Milano, Italy
}

\section{A R T I C L E I N F O}

\section{Keywords:}

Loess

Middle palaeolithic

Human mobility

MIS 3

Po plain

Italy

\begin{abstract}
A B S T R A C T
The final Middle Palaeolithic of northern Italy is almost exclusively known based on pluristratified sites in caves or rock shelter, which attest a certain technological variability within the Mousterian through the adoption of different knapping methods focused on the production of flakes or blades. The almost total lack of specialized and/or short-term open-air sites framed at this stage contributes to create a fragmentary and incomplete picture with regard to the last Neanderthal occupation of the area. For this reason, the Monte Netto site, an isolated hill at the northern margin of the Po Plain and at the foot of the Prealps, represents a key deposit to investigate this phase. Along the loess-palaeosoil sequence, investigated from a geochronological and pedological point of view, frequentations by Mousterian Neanderthal groups are attested at two different times, of which the most consistent is: associated to sediments dated to $44,400 \pm 5.4 \mathrm{ky}$ BP. The findings confirm the sporadic frequentation of marginal open areas during the cold, arid and highly fluctuating climate of the MIS 3, providing a more complete picture of the human occupation along the Po Plain Loess Basin (PPLB). An interregional comparison points out the clear intention, by the last Neanderthal groups of the Po Plain, of producing elongated supports by applying different methods, within a varied and organized system of resources exploitation evidenced by the selection of raw materials coming from more than $60 \mathrm{~km}$.
\end{abstract}

\section{Introduction}

Reconstructing the settlement systems of the late Neanderthals is one of the main topics of anthropological research aimed to achieve data for assessing population dynamics at the dawn of their demise in Europe. However, several shortcomings constrain research into too limited opportunities for inferring the reconstruction of the landscape these hominins moved across. Numberless are the cases where the reconstruction of human activity at a cave is largely more detailed than off-site due to the lack of data from open-air sites. The north of Italy does not escape this situation (Peresani, 2011), especially in eastern Lombardy, where the knowledge of human peopling is extremely fragmentary; this is due mainly to a series of factors that restricted the identification of sites dating to this period. For instance, the Mid-Upper Pleistocene activity of alpine glaciers and related outwash streams greatly contributed to obliterate traces of Pleistocene human occupation along the main valleys, on their outlet in the Po Plain and in most of the end-moraine systems. Almost the entire Po Plain has been subjected to repeated events of fluvioglacial and fluvial sedimentation that deposited meters of gravels and finer sediments submerging the Middle Palaeolithic open-air occupation layers to considerable depth (Monegato et al., 2017; Ravazzi et al., 2012).

However, a few Palaeolithic archaeological contexts protected from depositional or erosive events are almost exclusively located upon isolated hills, residual terraces and plateaus, which arise the mean altitude of the Po Plain. For instance, the outermost arc of the Garda Lake moraine amphitheatre, which formed before to the Last Glacial Maximum (LGM - Middle Pleistocene according to Venzo, 1957; Cremaschi, 1987a; Bini and Zuccoli, 2004; Monegato et al., 2017), represents a favoured topographic context. Moreover, isolated hills that are the surface expression of buried tectonic structures belonging to the South-Alpine front (Desio, 1965; Bersezio et al., 2001; Livio et al., 2012) played a fundamental role in preserving evidences related to the Middle Palaeolithic. Among isolated hills, particularly important are the Castenedolo and Monte Netto hills, which are located in the alluvial plain south of Brescia. These hills have been affected by repeated loess depositions during Marine Isotope Stages (MIS) 4-2 that sealed Mousterian open air sites (Baroni, 1986; Baroni et al., 1986, 1988;

\footnotetext{
* Corresponding author.

E-mail addresses: davide.delpiano@unife.it (D. Delpiano), marco.peresani@unife.it (M. Peresani), stefano.bertola@unife.it (S. Bertola), mauro.cremaschi@unimi.it (M. Cremaschi), andrea.zerboni@unimi.it (A. Zerboni).
} 
Cremaschi, 1974; Livio et al., 2012, 2014; Zerboni et al., 2015).

On the top of the Monte Netto Hill (Capriano del Colle, BS), Mauro Cremaschi (1974) uncovered archaeological materials dating back to different Palaeolithic phases. Furthermore, a recent survey in a quarry site (Zerboni et al., 2015) allowed the identification, again on the top of the hill, of an open-air Middle Palaeolithic context, buried and preserved by a loess sheet, and occasionally older archaeological materials. This contribution illustrates the archaeological discovery discussing the paleoenvironmental and the taphonomic contexts and offering the contextualization of the site at a regional level.

\section{The Middle Palaeolithic of eastern Lombardy and its} significance in the context of the Po plain open-air sites

The evidence of Mousterian sites in eastern Lombardy is evanescent for the reasons given above. Regarding the area south of the Garda Lake, traces of frequentations are known on the top of hills between Montichiari and Carpenedolo (primarily Monte Rotondo and to a lesser extent Monte San Giorgio, Monte San Zeno and Monte Fogliuto), where lithic artefacts have been found within palaeosoils, whose genesis predate the deposition of loess covers (Coltorti and Cremaschi, 1978; Coltorti, 1980). Other evidence is, as well as on the Ciliverghe Hill (Fig. 1), isolated hillock and westernmost point of the Garda moraine system, probably formed in the Lower-Middle Pleistocene (Cremaschi, 1987a; Baroni and Cremaschi, 1986; Baroni et al., 1986).

Further contexts that preserve isolated artefacts are located outward the western Garda Lake moraine amphitheatre near Gavardo (Fig. 1), in an area characterized by loessic deposits related to the Early-Middle Pleistocene moraine of Monte Faita (Montacoli, Limone, Rampeniga, Terzago and Moniga del Bosco sites), as well as sporadic attestations: Ca' dei Grii at Rezzato, a cave site at the foothills of the pre-Alps (Biagi and Marchello, 1970); Fornace Ferretti at Gavardo (Baroni et al., 1986); Cariadeghe at Cascina Buco del Latte site on the top of a karst plateau
(Cremaschi, 1981; Baioni, 2012). The sole presence of rare lithic tools referable to sporadic occupations and the total absence of associated faunal remains and radiometric dating have precluded the development of cultural and ecological considerations. The only charcoal assemblage associated with lithics, found at the bottom of a loess layer at the site of Cascina Buco del Latte (Fig. 1), indicates the presence of a nearby forest related to wet and temperate climate (Cremaschi, 1981).

From a chronological and ecological point of view, it is clear the connection between the Middle Palaeolithic open-air sites and the topographic surfaces buried by loess deposited close to the Pre-Alpine margin (Fig. 1). On a geoarchaeological and palaeopedological basis, correlated human frequentation was almost contemporary to loess deposition that in the region is preserved starting from MIS 4 (Zerboni et al., 2015). This is generally confirmed by surface patination on artefacts that would indicate deposition during the Würmian loess sedimentation (according to Cremaschi, 1981; Baroni et al., 1986), which corresponds to the MIS 4-3 loess.

This connection emerges even more clearly if the range of action is extended to the whole Quaternary Po basin, including the northern and southern foothills of the Po Valley down to the Marche region (Cremaschi, 1990). Hundreds of open-air sites are located on the Pleistocene relict terraces placed at the foot of the Apennine and Alpine margins, on hills and isolated mountains and plateaus inside the mountain ranges; these deposits are both significant and difficult to investigate and contextualize (Peretto, 1990). In the case of composite pedosequences comprising different loess covers and palaeosoils formed between the Middle and Upper Pleistocene, the sole study of the lithic assemblages based on typological indices, retouched tools, and presence/absence of Levallois and bifacial techniques doesn't allow the actual scan between Lower and Middle Palaeolithic in the region. In addition, in this perspective accurate geochronological analyses become more and more necessary, on the line of what has been done for the loess of the northern Apennine margin bearing Mousterian industry

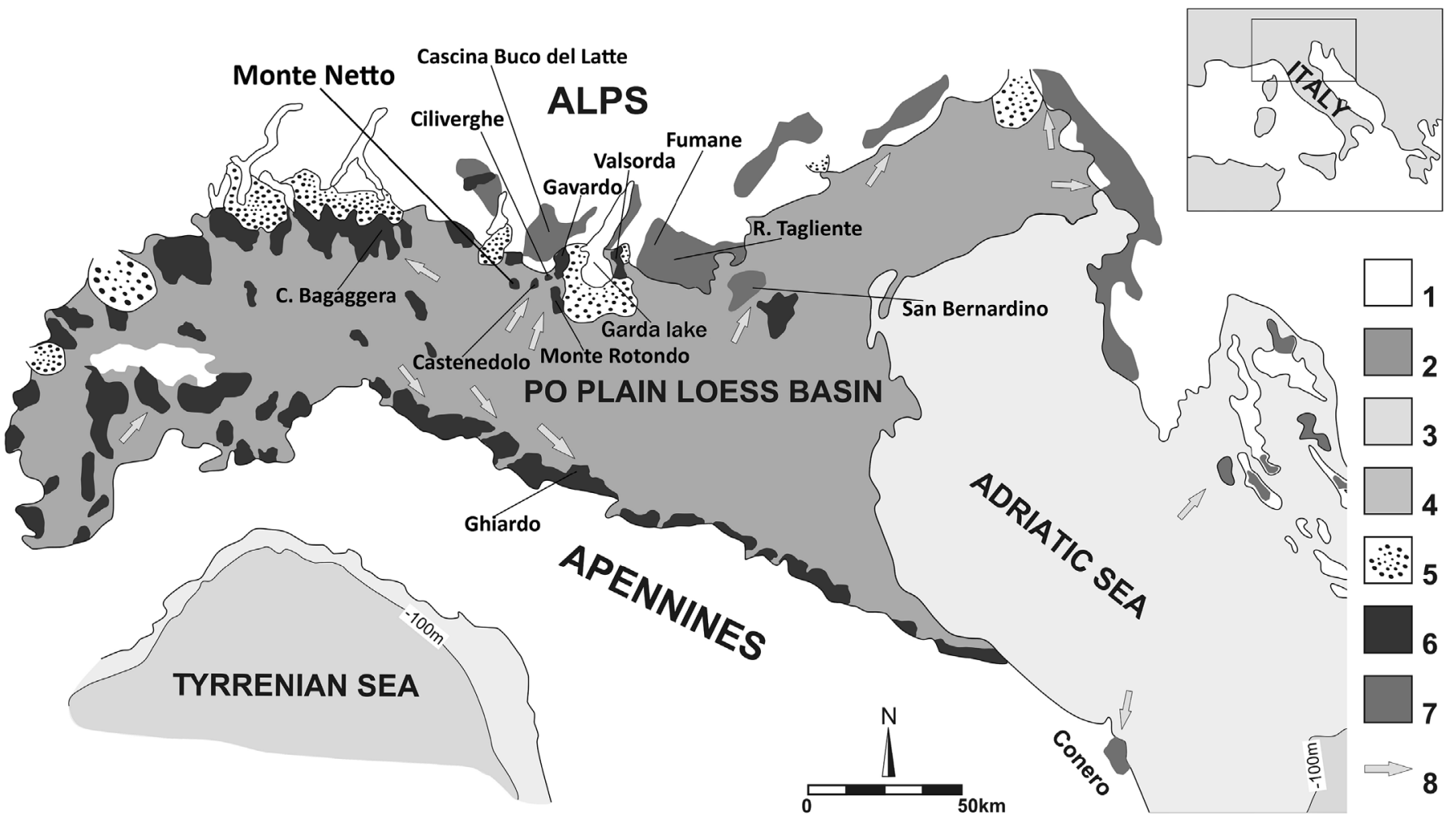

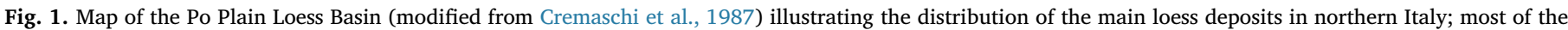

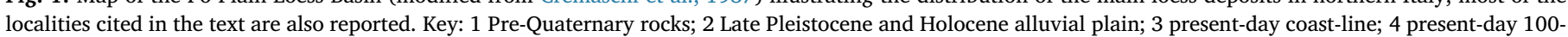

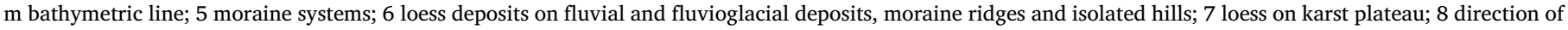
dominant winds during loess sedimentation. 
(Cremaschi et al., 2015), and for some sites near to the southern Alpine margin (Cremaschi et al., 1990). Therefore, the chrono-cultural context of open-air sites is, in most cases, partial and sketchy, often insufficient for the purpose of an inclusion in a global northern Italian perspective of the Late Middle Palaeolithic, known mostly on the basis of sheltered sites or caves in the Veneto and Friuli regions (Peresani, 2011, 2012; et al., 2013; 2014; Jéquier et al., 2015; Delpiano et al., 2018).

\section{The finding context}

\subsection{Monte Netto site: old and fresh investigations}

The Monte Netto Hill (Capriano del Colle, Brescia) is located $8 \mathrm{~km}$ South-West to the city of Brescia and the Prealps; placed at the top of a Late Quaternary anticline, it was uplifted and slightly folded by the compressive tectonic regime characterizing the Alpine foredeep. The hill is presently sticking out from the surrounding piedmont surface due to the cumulative co-seismic growth of compressive structures over the Late Quaternary (Livio et al., 2012). Therein, a loess-palaeosoil sequence was exposed at several clay quarries opened at the hilltop since the seventies and are still active. Monte Netto emerges from the plain for an altitude varying from 15 to $35 \mathrm{~m}$, and the discovery of lithic artefacts, about twenty flakes and tools, occurred since those years not in a primary context. They were collected on the northern slope of the hill around the "Cascina la Torrazza" locality, in the ground mixed up by quarry work, inside quarries, or on the surface near to the outcrops of weathered deposits. The absence of traces of fluvial transport and the presence of surfaces reddish patina that can be associated with the fersiallitic soils evolved on aeolian silts deposited prior to the last interglacial (Cremaschi, 1981). This testifies sporadic but extensive insitu human frequentations of Neanderthal groups focused on the production of retouched tools (scrapers, denticulates, dejeté point) in which the Levallois method is almost absent and stronger affinities emerge with Quina techno-complexes, in particular with the evolved French Tayacian (Cremaschi, 1974, 1981). Monte Netto also yielded a frontal end-scraper manufactured on a large blade ascribable to the Upper Palaeolithic on techno-typological base and also for the glossy patina that would indicate the burial in Upper Pleistocene loess (Cremaschi, 1981).

Since the 2000s, new and intense excavations of the fine deposit aimed to the production of industrial bricks have affected the central part of the flat summit of the hill (Laterizi Danesi quarry) placed about $1 \mathrm{~km}$ south of the area of the previous finds, exposing the entire sequence and providing the opportunity for extensive investigation on the morphological evolution of the hill (Livio et al., 2012, 2014; Zerboni et al., 2015). During field surveys, further artefacts have been found and documented embedded in their layers, making possible the cultural contextualization of the Neanderthal frequentations on this mound.

\subsection{Geoarchaeological investigation}

The Monte Netto Hill area was intensively surveyed in order to reconstruct its geomorphological and sedimentological evolution during the Middle to Upper Pleistocene; the most significant and complex pedosedimentary sequence locates in the area of the Laterizi Danesi clay quarry and was considered for detailed palaeopedological investigations (Livio et al., 2012, 2014; Zerboni et al., 2015).

One of the quarries currently active at the top of the hill exposes along a hundred metres long front up to ca. $8 \mathrm{~m}$ of weathered fluvial and fluvioglacial deposits, sealed at the top from a loess deposit ( $\leq 4 \mathrm{~m}$ ) interlayered with palaeosoils with different degrees of pedogenesis (Fig. 2). This sequence has been previously subdivided in pedostratigraphic levels (PL) and soil horizons, and investigated using field description of the sequence, sedimentological, heavy minerals and micromorphological analyses and radiometric dating summarized in Zerboni et al. (2015).
The lower part of the exposed section consists of strongly weathered colluvial sediments overlying fluvial and fluvio-glacial deposits dating to the Middle Pleistocene. In the upper part, the pedosedimentary sequence consists of several loess layers showing different degrees of alteration (Fig. 3); A tentative model of the exposed profiles involves the progressive burial of the anticline, which forms the core of the hill, by loess strata during MIS 4 and 3 according to OSL dating and their subsequent weathering (and truncation) during interstadials (Zerboni et al., 2015). The degree of weathering of buried B horizons increases from the top to bottom of the sequence suggesting a progressive decrease in the intensity of pedogenesis.

\section{Materials and methods}

The archaeological finds have been discovered in an area of about $30 \mathrm{~m}^{2}$, which was affected by mechanical excavations followed by archaeological control. The stratigraphic position was recorded for each piece; moreover, other artefacts come from surface collections, exposed by the erosion of loess levels saved by quarry activities.

Given the small number of artefacts, it was not possible to apply an extensive techno-economic analysis aimed to reconstruct the reduction sequences specific to each lithic raw material units (LRMU). Each piece has been analyzed individually through the registration of morphometric data and technological features: preparation of striking platforms and flaking surfaces, scar-pattern on the dorsal faces and the retouch modes and working-steps (Inizan et al., 1995; Andrefsky, 1998). Lithic raw materials have been described and grouped on the basis of physical features detected at variable magnification; microfacies have been screened under a stereomicroscope (12 up to 93 magnifications) in the laboratories of the University of Ferrara and have been compared to the geological samples collected in the eastern Lombard and western Venetian Prealps. Further analyses considered the still preserved natural surfaces on some artefacts for inferring the nature of the provisioning context (stream bed, glacial till, soil or palaeosoil; primary exposure outcrops or slope waste produced from primary exposure).

Finally, at the Museo Civico di Scienze Naturali in Brescia it was possible to analyze the old collections of the Cascina Torrazza site for a first comparison with the physical and taphonomic characteristics of the two groups of artefacts and infer their possible provenance from the same contexts. Conformities or differences between the assemblages were further investigated by means of technological comparisons and identification of raw materials and exploitation strategies.

\section{Results}

\subsection{The lithic assemblages}

The analyzed sample counts 20 products, 18 of which were collected at the top of the palaeosoil of unit PL2 (layer PL2, horizon 2Bt) (see Zerboni et al., 2015 for detailed description of the pedostratigraphic units), dated to $44,400 \pm 5.4 \mathrm{Ky} \mathrm{BP}$, while 2 items come from lower and not directly dated levels corresponding to the buried palaeosoil of unit PL4 (layer PL4, horizon 4Bt).

The analysis of stratigraphically higher finds (PL2, horizon 2Bt) reveals, despite the small number, a variety of knapping methods oriented to the preferential obtaining of fairly elongated blanks having straight and parallel or convergent cutting edges (Table 1; Fig. 4). The fresh aspect of these knapped stones indicates that no post-depositional movements took place, and the glossy surface of the fine-grained products can be ascribed to wind abrasion from quartz grains. Comparable alterations have been observed at the Ghiardo site and related to the loess depositional environment (Cremaschi et al., 2015, 2016).

The Levallois technical system is present and well testified by at least 7 blanks (Fig. 4: b, e, g): 4 are laminar flakes, including a coreedge removal flake with cortical back and three flakes with parallel to 


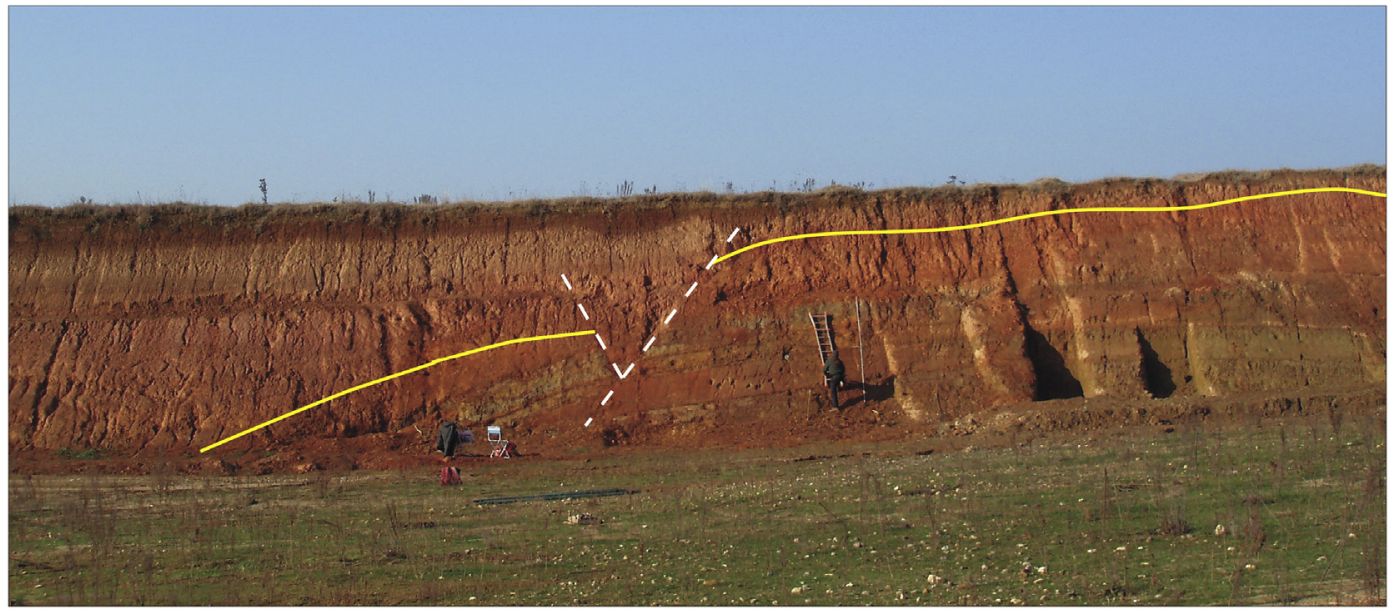

Fig. 2. Loess/palaeosoils exposure along an anticline at Monte Netto; loess strata are above the yellow line that marks the top of the red soil on fluvio/fluvioglacial sediments. White dotted lines indicate a brittle, secondary, fold-related faulting, dislocating loess strata and palaeosols in the central part of the anticline (Livio et al., 2009). (For interpretation of the references to colour in this figure legend, the reader is referred to the Web version of this article.)

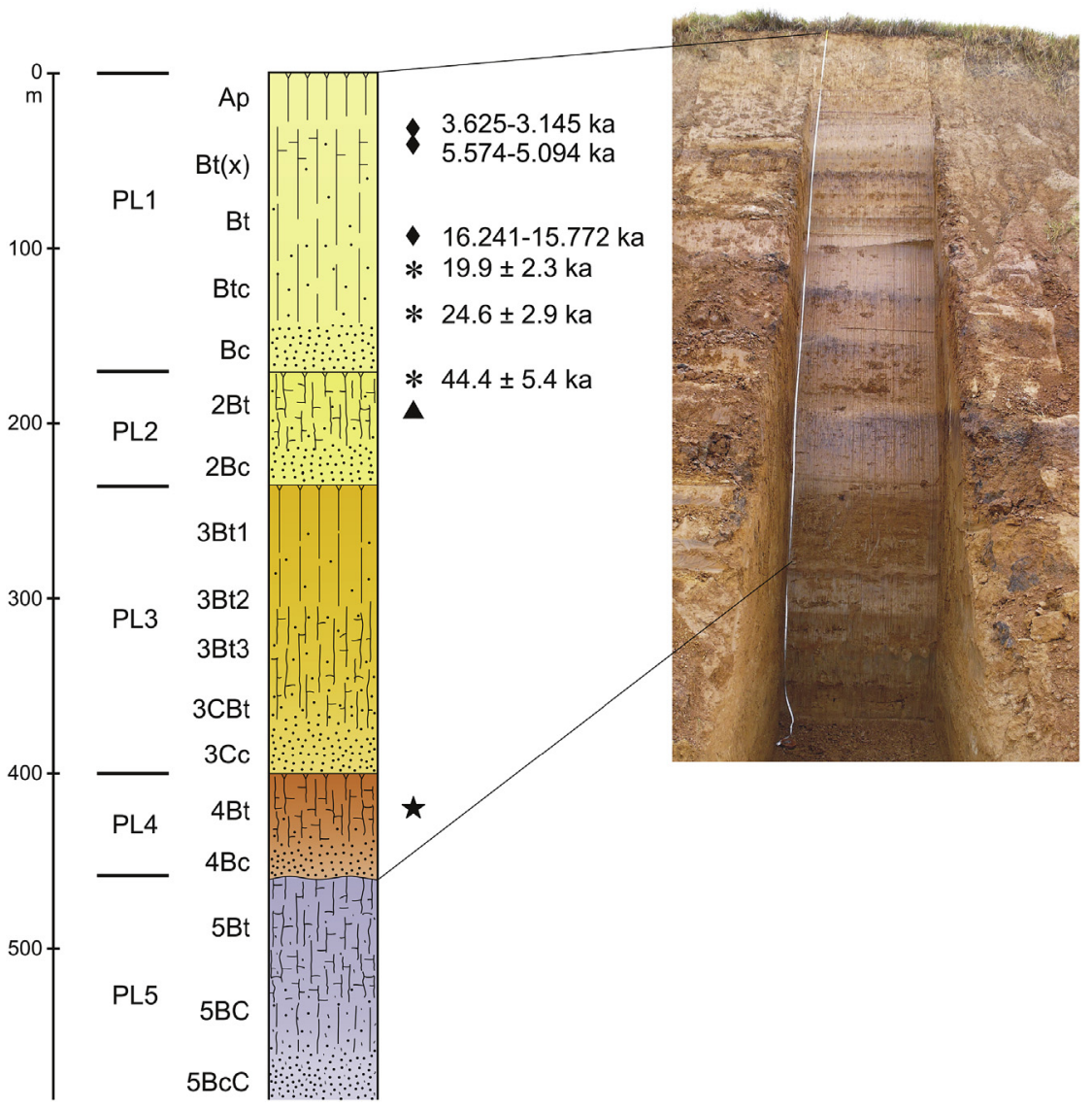

Fig. 3. The section described at Monte Netto indicating the distribution of soil horizons and the main pedostratigraphic levels (modified after Zerboni et al., 2015). The position of OSL (asteriks) and AMS- ${ }^{14} \mathrm{C}$ (diamonds) dating results are indicated. The black triangle is the stratigraphic position of the Late Mousterian archaeological findings; the star indicates the position of quartzite artefacts. The picture represents the main profile investigated, which is located at the southern fringe of the quarry.

Table 1

Technological features of the two analyzed lithic assemblages.

\begin{tabular}{lll}
\hline & PL2-2Bt & PL4-4Bt \\
\hline Core-shaping flakes & 2 & 2 \\
Levallois flakes & 7 & $\backslash$ \\
Unidirectional non-Levallois flakes & 3 & $\backslash$ \\
Discoid flakes & 2 & $\backslash$ \\
Undifferentiated/fragmentary flakes & 3 & $\backslash$ \\
Other & 1 & $\backslash$ \\
\hline
\end{tabular}

converging edges also designed from the retouch that was invasive on one piece and marginal on a second one. Two blanks are short Levallois flakes (one is very small and hinged) and the remaining is a fragmentary partially cortical flake. Butts are facetted, thicknesses range from 4 to $9 \mathrm{~mm}(6.4 \mathrm{~mm}$ on average) and the patter of the scars on the dorsal face reflects to the recurrent unidirectional modality ( 4 cases), the recurrent orthogonal (two cases) and possibly the preferential modality in one case, although heavily transformed by retouch.

Three artefacts record a unidirectional laminar technical system (Fig. 4: a, c, d) characterized by surface exploitation and low preparation of the striking platforms (butts are mostly flat or slightly facetted) 


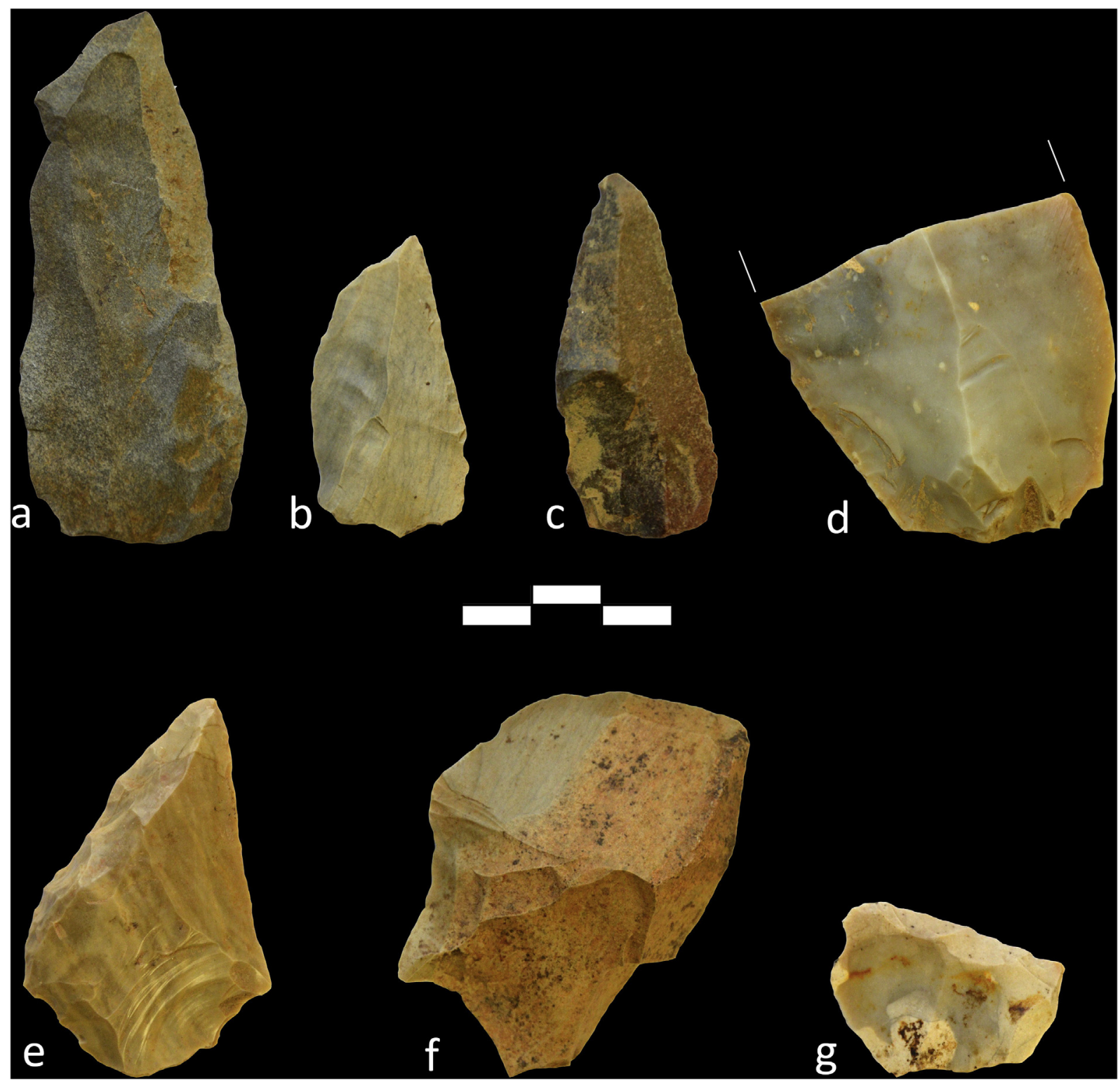

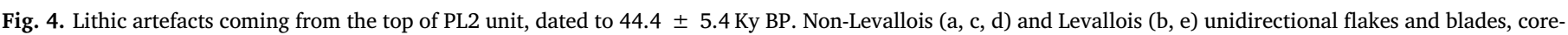

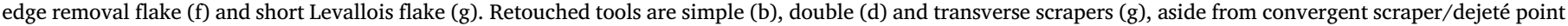
(e).

aimed to obtain elongated blanks with much greater thickness compared to the Levallois flakes (11 $\mathrm{mm}$ on average). In particular, we report the presence of a blade $\sim 8 \mathrm{~cm}$ long having converging edges ending in a tip and a unidirectional flake that is fragmented in the mesial portion but that was supposed to reach presumably $10 \mathrm{~cm}$ length. These products carry traces of neocortical surface in two cases.

Among the remaining artefacts, there are two thick core-edge removal flakes obtained with Discoid technological system (one is Fig. 4, f), characterized by fully or partially cortical back, typical centripetal scar-pattern and convex cutting edges. The too fragmentary conditions of 5 other artefacts obstacles the recognition of the flaking systems: these are two fragments of cortical flakes produced in the early stages of core shaping and three undifferentiated fragments. Finally, we note a fluvial pebble that may have been used as a hard hammer though the traces look not markedly evident and limited on the two opposite poles. There are no cores in the assemblage.

There are also retouched tools $(n=7)$, shaped on Levallois blanks: one short flake, three blades, two cases unidirectional flakes and one fragmentary cortical flake. These tools refer almost exclusively to scrapers, including: one scraper from converging to slightly déjeté point (Fig. 4, e), two laminar flakes converted into simple lateral scrapers (one is a scraper-borer, Fig. 4, b) and a transverse scraper on short flake (Fig. 4, g). There is also a double bi-convex scraper made on a large and incomplete unidirectional flake (Fig. 4, d) and one transverse scraper on a cortical fragment. Also an undifferentiated fragment presents a slightly denticulate inverse retouch. In all the other cases described above, the retouch is direct, simple and marginal; only the déjeté point has a margin with invasive retouch.

Many products bearing limited traces of cortical surfaces testify the introduction onto the site of cores or blanks already partially shaped; the presence of two fragments with thermal alteration presumably due to anthropic action is also noted.

The artefacts collected within the basal part of the stratigraphic sequence (PL4, horizon 4Bt) are only two un-retouched flakes made from two pebbles and therefore too few in order to advance overall techno-typological considerations (Table 1). However, differences by respect to the assemblage described above are striking (Fig. 5). The different stratigraphic position is also marked by the presence of thick 


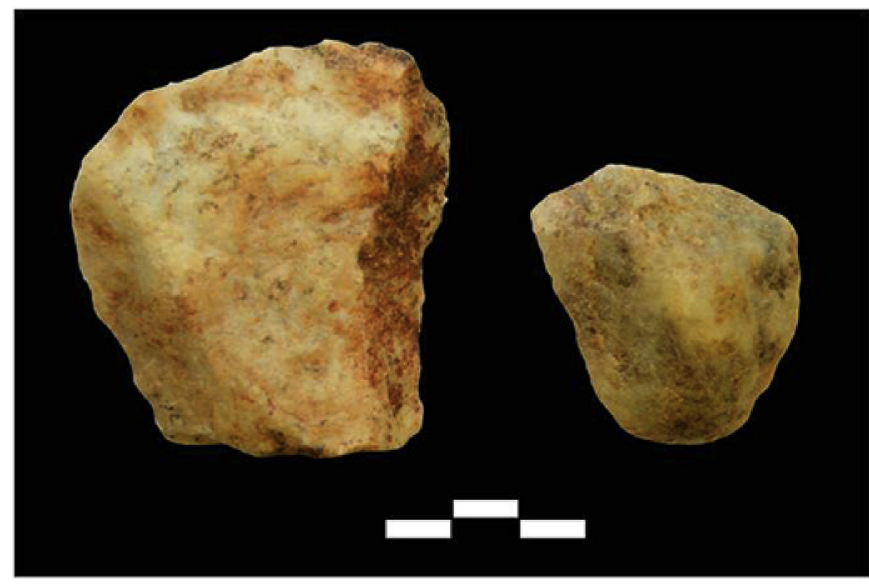

Fig. 5. Lithic artefacts coming from the lower unit PL4: two flakes obtained from the opening of quartzite cobbles.

red patina (coating of reddish illuvial clay) testifying the embedding in the red palaeosoil of PL4.

\subsection{Raw materials}

The assemblage is composed of a quite heterogeneous group of cherts, two quartzites and one rather immature sandstone with heterogeneous lithic clasts. Quartzite artefacts are from horizon 4Bt of pedostratigraphic level PL4, the remnant artefacts are from unit PL2, horizon 2Bt. Generally, for the cherts we observe a more targeted selection, given their collection occurred in different contexts, even from distant sources (Table 2).

The two quartzite flakes are made of a microcrystalline, white-milky variety of metamorphic origin and by a second variety having large pegmatitic crystals of magmatic or filonian origin. The sandstone is represented by a short used pebble/hammer made from the Verrucano Lombardo formation (Upper Permian). The preserved natural surfaces of these three artefacts have well-rounded morphologies with traces of fluvial transport thus suggesting their collection from torrent deposits. A possible source is the large alluvial fan of the Val Trompia (a few $\mathrm{km}$
$\mathrm{N}$ of the site), where these lithologies have been transported downstream for several kilometers from the outcrops by the ancient and actual Mella River.

The cherts assemblage $(n=17)$ refers to the Jurassic-Cretaceous succession of the Southalpine emerging in two different and contiguous paleogeographic contexts: the Lombard basin (to the west) and the Trento plateau (to the east), roughly separated by the Garda Lake (Fig. 6). The Lombard basin $(n=13)$ primary sources cherts are distributed in the south-eastern Lombardy Prealps (Bertola et al., in press) and crop out in a $30 \mathrm{~km}$ radius straight-line from the site. However, they were collected in secondary contexts, especially soils or palaeosoils, as clearly attested by the morphology and chemical alteration of the cortexes. The exploited varieties belong above all to the Concesio Group (Middle Jurassic) ( $n=9$,), whose outcrops, located between the Monte Covolo and the Monte Pizzoccolo, are particularly rich in fine texture, good to excellent knappable gray-green cherts, mainly nodules also of medium-large size, characterized by diagenetic concentric laminations and thick marly light brown cortexes.

Other rarely used lithotypes are the slightly silicified cherts of the Gardone Val Trompia formation (Medolo Group, Lower Jurassic) $(n=1)$, the vitreous but often fractured varieties of the Selcifero Lombardo Group (Lower-Middle Jurassic): Radiolarites $(n=1)$, Rosso ad Aptici $(n=1)$ and finally the Scaglia Rossa Lombarda (Upper Cretaceous) ( $n=1)$, having large calcareous impurities that hinder the knapping. Overall, these are cherts with noticeable limits regarding the workability and integrity of the blocks.

The cherts referable to the Trento plateau (Bertola, 2016) $(n=4)$ are represented by two varieties of Maiolica (Lower Cretaceous) $(n=3)$ and one of Tofino Limestone (Middle Jurassic) $(n=1)$. Their primary outcrops are distributed in the western Lessini mountains, within a $60 \mathrm{~km}$ straight line radius from the site. It is also possible to find cobbles in the eastern Garda moraines (Fig. 6) but they are often diaclased and unsuitable especially to produce large blanks.

The Tofino Limestone (Middle Jurassic) was deposited in the connection area between the Trento plateau and the Lombard basin. It is a grainstone with bioclasts (ooliths, echinoderms, spicules of sponge, gastropods, pellets) very characteristic of the area and widely used in the Middle Palaeolithic for the big size and homogeneity of the blocks that allowed the production of large flakes. The Monte Netto artefact

Table 2

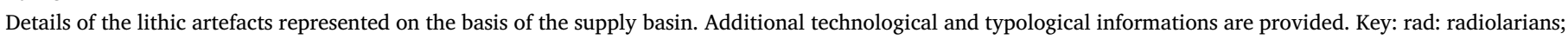

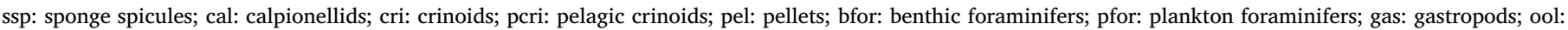
ooliths.

\begin{tabular}{|c|c|c|c|}
\hline Lombard basin $(<30 \mathrm{~km})$ & Chert/Rock & Product & Tipology \\
\hline Medolo & Packstone (ssp, rad, bfor) & Unidirectional flake & Lateral Scraper \\
\hline Concesio & Wackestone (rad, ssp) & Levallois flake & Scraper + Bohrer \\
\hline Concesio & Wackestone (rad, ssp) & Unidirectional flake & - \\
\hline Concesio & Wackestone (rad, ssp) & Levallois flake, debordant & - \\
\hline Concesio & Wackestone (rad, ssp) & Levallois flake & Trasversal Scraper \\
\hline Concesio & Wackestone (rad, ssp) & Discoid flake, debordant & - \\
\hline Concesio & Wackestone (rad, ssp) & Levallois flake, semidebordant & - \\
\hline Concesio bioarenitic & Packstone (rad, ssp, cri, pel, bfor) & Discoid flake, debordant & - \\
\hline Concesio & Wackestone (rad, ssp) & Flake fragment & - \\
\hline Concesio bioarenitic & Packstone (rad, ssp, cri, pel, bfor) & Indeterminable & - \\
\hline Radiolariti & Wackestone (rad) & Flake & - \\
\hline Rosso ad Aptici & Wackestone (rad, pcri) & Indeterminable & - \\
\hline Scaglia Lombarda & Wackestone (pfor, rad) & Cortical flake & Scraper fragment \\
\hline Quarzite 1 & Microcrystalline, metamorrphic & Cortical flake & - \\
\hline Quarzite 2 & Macrocrystalline, magmatic/filonian & Cortical flake & - \\
\hline Verrucano & Sandstone & - & Hammerstone \\
\hline Trento plateau ( $>60 \mathrm{~km})$ & Chert/Rock & Product & Tipology \\
\hline Tofino & Grainstone (ool, cri, ssp, gas, bfor) & Levallois flake & Lateral Scraper \\
\hline Maiolica B1 & Wackestone (cal, rad, ssp) & Levallois flake & Convergent Scraper/Dejeté point \\
\hline Maiolica B2 & Wackestone (rad, pfor) & Unidirecional flake & Double Lateral Scraper \\
\hline Maiolica B2 & Wackestone (rad, pfor) & Levallois flake & - \\
\hline
\end{tabular}




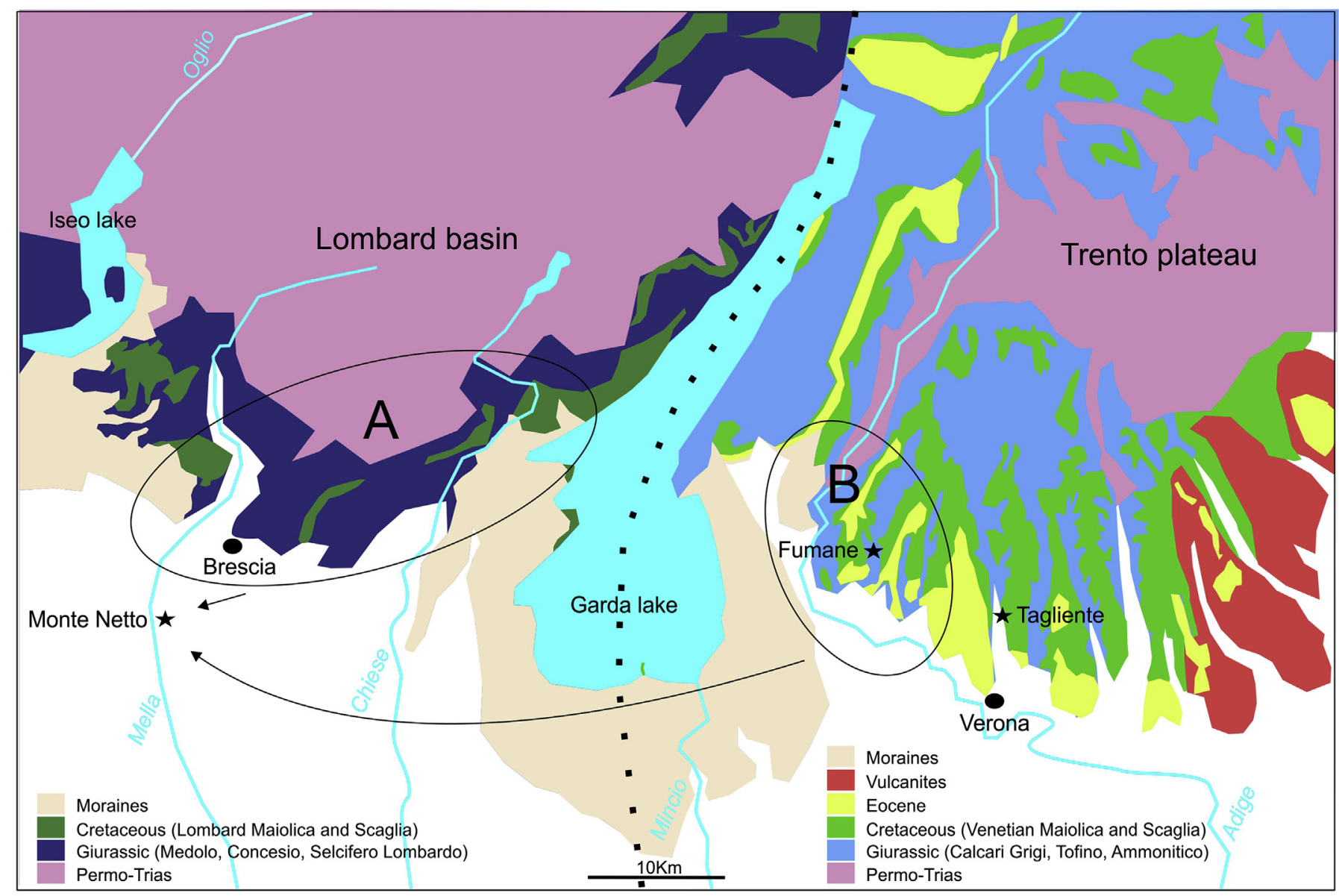

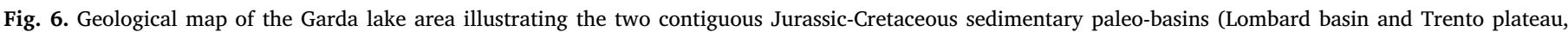

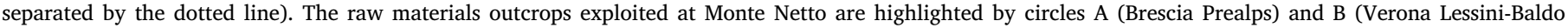
Prealps).

was obtained from a well-rounded pebble of fluvial or fluvioglacial origin.

Regarding the Maiolica, it was indeed an appreciated chert for its excellent quality (fine crystalline, easy to work). There are no residual natural surfaces from which the source context can be inferred, but it is probable that the raw material comes from areas located near high quality primary outcrops, higher quality sources. One of the artefacts was made on a brownish-yellowish variety typical of the lower portion of the formation (type B1), indeed typical of this area. Two other artefacts were made from light gray varieties (type B2) which are stratigraphically higher positioned.

\subsection{Old collections}

Among the materials coming from the quarries open on the top of Monte Netto in the last decades, there are artefacts from different periods, mainly Middle and Upper Palaeolithic and Mesolithic. Only those almost certainly ascribable to the Middle Palaeolithic, about thirty and coming from Cascina Torrazza site, have been here re-analyzed in order to perform a techno-typo-taphonomic comparison with the more findings recently discovered. Most of the pieces present a quite fresh physical state with light whitish patinas on flints or darker on coarser grained raw materials, as well as glossy surfaces due to burial in loess. A Levallois flake (recycled through more recent retouch) is characterized, however, by developed yellow patina and traces of fluvial transport; the same traces and black manganese patina affect a couple of artefacts whose attribution to Middle or Upper Palaeolithic is doubtful: these are a simple burin and a small bladelet core with slight exploitation and surface preparation. Among the cores, a recurrent centripetal Levallois core is present, as well as two small undifferentiated flake cores and a fragment which could correspond to a Levallois unidirectional core. Among the raw blanks, however, the Levallois flakes are the minority $(n=5-6)$, evenly divided distributed unidirectional, orthogonal and centripetal patterns. There are also short unidirectional, centripetal and undifferentiated core-edge removal flakes and numerous semi-cortical products that testify short reduction sequences carried out on site. The retouched tools mainly refer to a large variety of scrapers on thick and slightly elongated flakes, not manufactured with the Levallois method apart from the aforementioned simple scraper, then recycled in a scraper-notch. A bilateral scraper endscraper, a large simple scraper with a flat/simple scalar retouch, and a déjeté point having invasive scalar retouch are also noteworthy.

\section{Discussions}

\subsection{Monte Netto: an open-air, pluristratified site}

If we consider only the archaeological artefacts collected in situ in the stratigraphy and given their sparse distribution, it is evident that Monte Netto was characterized by short-term, but repeated human occupation pattern. These evidence are significant because they attest the sudden transit of Neanderthals at the margins of the Po Plain, which fits the open-air sites scenario of Northern Italy and represents a strong ecological counterpart with the high-frequence occupations attested, conversely, in the pre-Alpine caves, especially in the Veneto pre-alpine and sub-alpine range (Peresani, 2011). Furthermore, by crossing this 
information with the geological and geochronological data in order to contextualize the repeated occupations recognized on the hill, the scenario is enriched. Chronological scans within the Mousterian frequentations are in this way outlined, and elements for reconstructing the human-environment relationship in the Upper Pleistocene of the Po basin can be inferred.

At least two distinct phases of occupation by the Neanderthals are evident at Monte Netto.

- At first, the ephemeral anthropic presence corresponding to PL4, horizon $4 \mathrm{Bt}$ seems to be short and characterized by opportunistic technological behavior: the quartzite flakes represent the first stages of short lithic operational sequences that took place after a strictly local supply of a poor quality raw material, collected from the glacial and fluvioglacial gravels emerging on the hill or along the bed of the ancient Mella River that still today, from Valtrompia Valley, flows at the side of Monte Netto (Fig. 5). Only pebbles opening and the obtaining of simple cortical blanks with a cutting edge is documented for this older occupation phase, which is related to the presence of a topographic surface underlined by a reddish palaeosoil (a sort of Ferretto palaeosoil in the old Italian literature, see Cremaschi, 1987a), originated on colluvial deposits on the top of fluvial and fluvio-glacial units probably dated to MIS 5 (Zerboni et al., 2015). Although radiometric dating of these layers is not available, their deposition occurred before MIS 4 and 3 loess aggraded, as confirmed by direct OSL dating and several papers suggesting that the beginning of the aeolian deposition at the northern edge of the Po Plain Loess Basin (PPLB) started in MIS 4 (Cremaschi et al., 1987; 2011; 2015; Zerboni et al., 2015, 2018). The warm phase that formed the palaeosoil could therefore correspond to the Eemian (MIS5e).

- A subsequent phase of occupation of Monte Netto, corresponding to PL2, horizon 2Bt, dates to the end of the Middle Palaeolithic and the Neanderthal presence in Europe. Also in this case, the artefacts do not suggest a permanent settlement, but they correspond to occasional and strictly temporary passages. However, human groups that settled the hill during this phase are characterized by a well recognizable technological and ecological behavior that is properly integrated in the contemporary context between the Po Plain and the Alps (Peresani, 2011). At Monte Netto, Mousterians make common use of Levallois and unidirectional flaking methods in order to manufacture elongated tools such as blades and laminar flakes, often transformed into simple or double side scrapers (Fig. 4); also the short blanks are used and transformed through transverse retouch. The stages of reduction sequences present on site are few, attributable mainly to the obtainment and discard of the blanks and tools, used and in some cases exhausted or broken. This extreme spatial fragmentation of the operational chains is linked on one side to the absence of cores and on the other to the arrival of raw materials from more distant supply sites after a selection based on their physical (knappable) properties, mainly homogeneity and fine texture; some fresh and not altered cortical surfaces register the collection in the proximity of primary outcrops, and in four cases the flint comes from the western Lessini district, distant over $60 \mathrm{~km}$ from Monte Netto (Fig. 6).

Currently, difficulties arise if we try to integrate the collected data with the old assemblages from Monte Netto Cascina Torrazza, mainly because of the lack of a precise stratigraphic attribution of those artefacts. In addition to this, there is no direct techno-typological analogy that can help us in this sense. The glossy surface patination and the fresh state of most of the artefacts suggest a depositional phase consistent to the Upper Pleistocene and completely incorporated into the loess. Nevertheless, there is a certain taphonomic variety with pieces that typologically are attributable to the Upper Palaeolithic (burin, blade-endscraper and blade or bladelet cores), which in some cases bear heavy patination and traces of fluvial transport, and in others are affected by the same surface alterations of the Mousterian finds. In addition, the picture is made more intriguing by the presence of the recycled Levallois flake, perhaps collected elsewhere and here retouched, comparably to the pieces bearing double patination and exploited as cores or blanks for retouched tools in some caves of the Veneto area (Peresani et al., 2015).

From a cultural and techno-typological point of view, the two main lithic assemblages (Monte Netto Cascina Torrazza and Monte Netto Danesi quarry, PL2, horizon 2Bt) present few common elements in a general framework characterized by considerable differences which have led to classify the old assemblage (M. N. Cascina Torrazza) as Quina Mousterian or Tayacian (Cremaschi, 1974). Here, the Levallois method is not very present and well documented only in the centripetal variant, the desired blanks lack of laminarity, the tools have long lives with multi-phases (through "Quina" retouch) and are obtained on thick flakes or sometimes pebbles. Although the paleosol of origin could be the same, traces of different occupations that have followed in a relatively short period could be preserved within the same macrophase. Neanderthal groups of Quina techno-facies are generally associated with rigid climatic conditions documented especially in the colder periods of MIS 4 and 3 both in the South-Western France (Delagnes and Meignen, 2006) and in the rare northern Italian contexts in which it has been recognized (Peresani, 2012; Jéquier et al., 2015; Bertola et al., 1999).

These constrained environments directly influence the economic and behavioural strategies of the human groups, characterized in these phases by high mobility, witnessed by mobile tools that have long uselives and hunting strategies oriented towards migratory ungulates. During the same rigid conditions, the aeolian dusts that have incorporated the artefacts may have been deposited. In this case, possible different occupations can be flattened and homogenized by the continuous deposition of loess. The lack of precise stratigraphic attribution unfortunately can not give rise to inferences in this sense; moreover, the differences between the two assemblages could also be due to different functional activities carried out in two areas distant about $1 \mathrm{~km}$ as the crow flies.

\subsection{Monte Netto in the Po plain loess basin}

On the base of the cultural, chronological and pedostratigraphic resolution, the site of Monte Netto has made possible to shed light on the Neanderthal settlement dynamics outside the usual sources of evidence, which are preserved in caves and rock-shelters the off-site. Its significance in related to the peopling of the Upper Pleistocene Aeolian landscape in the Po Plain Loess Basin, previously documented both in open-air sites (Cremaschi and Peretto, 1977, 1988; Lenzi and Nenzioni, 1996; Cremaschi et al., 2015; Peresani and Nicosia, 2015) and inside rock shelters (Cremaschi, 2004) (Fig. 1). It has already been stated that the deposition of aeolian sediments at the margins of the Po Plain occurred organically throughout the basin (Accorsi et al., 1990; Cremaschi, 1987b, 1990; Cremaschi et al., 1987; Peresani et al., 2008; Amit and Zerboni, 2013; Zerboni et al., 2018), outlined in several episodes of sedimentation occurred between the beginning of MIS 4 and 3. An example is the case of the Ghiardo terrace, near Reggio Emilia, located on the southern margin of the Po Plain $\sim 100 \mathrm{~km}$ south of Monte Netto, whose loess strata with Mousterian lithic artefacts and initially positioned in the Middle Pleistocene, were attributed to the Upper Pleistocene on a chronometric basis between 70 and 60 ka BP (Martini et al., 2001; Cremaschi et al., 2015). At the northern fringe of the Po Plain basin, traces of Neanderthal occupation associated with loess sedimentation are evident in the aforementioned western Garda contexts, in which precise and reliable chronometric data are not currently available; the same occurs also in the eastern Garda area, where in the complex end-moraine system the pollen diagram of the Val Sorda loess sequence attests in MIS 4 and 3 ecological conditions of cold 
steppe landscape with rare arboreal cover (Accorsi et al., 1990; Ferraro et al., 2004, 2009). Findings of Mousterian artefacts are reported within the Val Sorda loess, referable to MIS 4 to 3 (Venzo, 1961).

In western Lombardy $65 \mathrm{~km}$ from Monte Netto, the open-air site of Cascina Bagaggera has produced traces of Mousterian occupation at the base of the loess profile, dated directly (OSL on burnt artefact) to 60.5 $\mathrm{Ka}$, in the first part of MIS 3 (Cremaschi et al., 1990). Finally, thin silty beds related to several phases of aeolian sedimentation have been recognized in some caves or sheltered contexts of the Lessini Mountains (about $60 \mathrm{~km}$ east from Monte Netto) characterized by intense human frequentation such as the Riparo Tagliente Shelter (levels 44-40) and Grotta Fumane Cave (levels A4 - BR11), with dates that fall in the first part of MIS 3 (Castiglioni et al., 1990; Peresani et al., 2008). Also in San Bernardino cave, located on the Berici Mounts, the deposition of loess occurred in several phases mainly in the external area of the cavity. Unit IV is attributed between the end of the MIS 5 and the MIS 4 and record open environment and cold dry climate, in correspondence with a rarefaction of anthropic traces (López-Garclia et al., 2017). It is evident from these data that during the cold and dry climatic phases that characterize the middle Upper Pleistocene (Amorosi et al., 2008), the Po Basin was inhabited by human groups adapted to survive the unfavorable climatic and ecological conditions. The most detailed pollen sequences available in northern Italy (Azzano Decimo and Fimon) underline, for MIS3, an environmental picture composed of boreal forest and steppe, increase of xerophytes species and peaks of coals related to dry and cold intervals with recurrent fires, in a definitely oscillatory general pattern (Pini et al., 2009, 2010).

\section{Final considerations}

In light of these data, the Monte Netto site is one of the main geoarcheological deposits in which it is possible to investigate the palaeoecological and settlement dynamics of the Neanderthals in Lombardy, becoming part of a picture characterized by short-term occupations at the northern fringe of the Po Plain.

Regarding the oldest occupation of the area, we underline the extremely sporadic character of the Neanderthal frequentation, as well as the opportunistic and not structured techno-economical behavior aimed to exploit strictly local and poor quality lithic raw materials in order to obtain flaked tools with immediate and short use. Comparisons on a territorial basis are not possible, even if the findings at Monte Rotondo site would have emerged in a similar stratigraphic position at the base of the loess resting on a weathered Middle Pleistocene glacial deposit (Cremaschi, 1987a). However, the characteristics of the assemblage would be more in line with the Monte Netto Cascina Torrazza site, displaying archaic technological features (Cremaschi, 1981).

The technological behavior of the most recent phase, marked by the presence of the Levallois method and oriented towards the production of elongated blanks, finds the closest comparisons in eastern Lombardy with Cascina Buco del Latte (Cariadeghe), Fornace Ferretti (Gavardo), S. Vigilio (Concesio), and in the western part of the region with Buco del Piombo, Caverna Generosa and Cascina Bagaggera sites, in which the Levallois method is attested even if faintly (Cremaschi, 1981; Cremaschi et al., 1990; Baroni et al., 1986; Fedele and Gagliardi, 1988; Bona et al., 2007). Clearer similarities emerge beyond regional boundaries, particularly with the final Middle Palaeolithic investigated in the nearby Veneto region. Just $60 \mathrm{~km}$ away opens the aforementioned cavity of Fumane Cave, whose sequence contains similar occupational layers (A5-A6 and A10) with respect to chronology and technical systems and objectives (Higham et al., 2009; Peresani et al., 2008, 2013; 2017). The Levallois reduction method in its recurrent unidirectional modality is here prevailing, with a substantial presence of Levallois blades and laminar flakes. The radiometric dates of the A5-A6 layers, in particular, match those of the Monte Netto sequence, and the presence in both sites of lithic raw materials belonging to reciprocal supply basins is a further attestation of cultural and/or physical circulation between the two areas in the Late Middle Palaeolithic (Delpiano et al., 2018). Similarly, along the Mousterian sequence of Riparo Tagliente, the adoption of different technical systems (unidirectional Levallois and unidirectional volumetric) is attested to obtain laminar blanks with different morpho-technical features. However, the blades are a non-exclusive and sometimes secondary objective in these occupations (Carmignani, 2017). Similarities are reported with other sites in the subalpine region dated to MIS3 such as Grotta San Bernardino Cave (Unit II) and the loessic contexts of the Northern Apennine margin (Cremaschi et al., 2010, 2015; Delpiano and Garbasi, 2016) whose OSL dates, on the basis of preliminary investigations, would be consistent or slightly older than Monte Netto ones. These parallelisms, in which Monte Netto site seems to fit, are significant in the cultural and technological context of the final Mousterian in the northern Italy, where the diversification of the technical systems used by the Neanderthal groups reaches its peak and systematically emerges the tendency to obtain elongated blanks.

Sites on terraces or hills such as Monte Netto, located in open areas close to the alluvial plain, had to be temporary settlements during wideranging movements or outposts aimed at obtaining food resources that, in the form of large mammals, had to roam in a sufficiently open territory like the Po Plain. On the contrary, sheltered sites placed in innermost regions rich in lithic and/or food resources could represent refuges for cyclical and periodic occupations with a more persistent outline (Peresani, 2011).

\section{Acknowledgments}

We would like to thank A. Berlusconi, L. Bonadeo, M.F. Ferrario, C. Frigerio, F. Livio, and A.M. Michetti for valuable help in the field, and P. Schirolli and M. Brunetti from Museo Civico di Scienze Naturali in Brescia for making available the analysis of Monte Netto Cascina Torrazza lithic assemblage. A deep acknowledgment is to Fornaci Laterizi Danesi S.p.A. for allowing us working in the area of their quarry, and to the Superintendence for the Archaeological Heritage of Regione Lomíbardia for continuous support to the responsible of the field investigation (A.Z.). This research has been carried out within the activities of the INQUA GEODUST International Focus Group. Financial support from Università degli Studi di Milano, Progetto Linea 2 (2016 and 2017) entrusted to AZ. Part of this study is supported by the Ministry of Education, University and Research (MIUR), Italy, through the project 'Dipartimenti di Eccellenza 2018-2022' awarded to the Dipartimento di Scienze della Terra "A. Desio" of the University of Milano. We are grateful to one anonymous reviewer for constructive suggestions. Author contributions: A.Z. and M.P. designed the research; D.D., S.B., M.P. analysed data; D.D., S.B., M.P., M.C., A.Z. wrote the paper.

\section{References}

Accorsi, C.A., Baroni, C., Carton, A., Cremaschi, M., Filippi, N., Magnani, P., Maggi, W., Nisbet, R., 1990. The loess at the Apennine fringe. In: Cremaschi, M. (Ed.), The loess in Northern and Central Italy: a loess basin between the Alps and the Mediterranean Sea. C.N.R., Centro di Studio per la Stratigrafia e Petrografia delle Alpi Centrale, Milano, Italy, pp. 73-101.

Amit, R., Zerboni, A., 2013. Report on the INQUA-AEOMED field-trip workshop 'reconsidering loess in northern Italy' (Po plain, 1-3 July 2013). AMQ - Alpine Mediterranean Quat. 26 (2), 11-15.

Amorosi, A., Pavesi, M., Ricci Lucchi, M., Sarti, G., Piccin, A., 2008. Climatic signature of cyclic fluvial architecture from the Quaternary of the central Po Plain, Italy. Sediment. Geol. 209, 58-68.

Andrefsky, W., 1998. Lithics. Macroscopic Approaches to Analysis. Cambridge Manuals in Archaeology, Cambridge.

Baioni, M., 2012. Il paradiso perduto. Il Paleolitico e il Mesolitico. In: Archeologia nella Lombardia orientale. I musei della rete Ma_Net e il loro territorio. All'insegna del Giglio, pp. 41-60.

Baroni, C., 1986. Rinvenimento di manufatti litici sulla collina di Castenedolo (Brescia). Nat. Brescia. 23, 385-386.

Baroni, C., Cremaschi, M., 1986. Geologia e pedostratigrafia della collina di Ciliverghe (Brescia). Nat. Brescia. 23, 55-78. 
Baroni, C., Cremaschi, M., Peretto, C., 1986. Recenti Ritrovamenti Paleolitici in Lombardia. Atti II Convegno Archeologico Regionale, 13/15 Aprile 1984, Como Villa Olmo. New Press, Como, pp. 363-378.

Baroni, C., Cremaschi, M., Fedoroff, N., 1988. The stratigraphy of the Castenedolo hill. In: Cremaschi, M. (Ed.), The loess in Northern and Central Italy: a loess basin between the Alps and the Mediterranean Sea. C.N.R., Centro di Studio per la Stratigrafia e Petrografia delle Alpi Centrale, Milano, Italy, pp. 61-72.

Bersezio, R., Fantoni, R., Pessina, C., 2001. L'assetto strutturale del margine Sudalpinopadano: Contributo alla conoscenza del sottosuolo nel settore bergamasco. Geol, Insubrica 6 (1), 81-93.

Bertola, S., 2016. Southern Alps (Trento plateau) and northern Apennines flints: ages and distribution. In: Tomasso, A., Binder, D., Martino, G., Porraz, G., Simon, P., Naudinot, N. (Eds.), Ressources lithiques, productions et transferts entre Alpes et Méditerranée. Séances de la Sociétè préhistorique francaise, Paris, pp. 55-75.

Bertola, S., Peresani, M., Peretto, C., Thun-Hohenstein, U., 1999. Le site paléolithique moyen de la Grotta della Ghiacciaia (Préalpes de Vénétie, Italie du Nord). L'Anthropologie 103/3, 377-390.

Bertola, S., Lo Vetro, D., Schirolli, P., Confortini, F., Malzanni, M., Pallecchi, P., 2018. Chert exploitation and circulation in the Lombard Prealps. A diachronic overview trough Prehistory (in press). Proc. UISPP Cong Paris.

Biagi, P., Marchello, G., 1970. Scavi nella cavernetta Ca' dei Grii (Virle, Brescia). Rivista di Scienze Preistoriche XXV, 1.

Bini, A., Zuccoli, L., 2004. Prime note sul rilevamento dell'Anfiteatro del Garda: metodi e unità provvisorie. Il Quaternario, Italian J. Quat. Sci. 17 (2/1), 333-342.

Bona, F., Peresani, M., Tintori, A., 2007. Les grottes à ours avec indices de fréquentation humaine au Paléolithique moyen final. L'exemple de la Caverna Generosa dans les Préalpes lombardes, Italie. L'Antropologie 111, 290-320.

Carmignani, L., 2017. Between the flake and the blade: associated systems of production at RiparoTagliente (Veneto, northern Italy). J. Lithic Stud. 4, 1.

Castiglioni, G.B., Cremaschi, M., Guerreschi, A., Meneghel, M., Sauro, U., Van Vliet Lanoe, B., 1990. The loess deposits in the Lessini plateau. In: Cremaschi, M. (Ed.), The loess in Northern and Central Italy: a loess basin between the Alps and the Mediterranean Sea. C.N.R., Centro di Studio per la Stratigrafia e Petrografia delle Alpi Centrali, Milano, Italy, pp. 41-59.

Coltorti, M., Cremaschi, M., 1978. Deposito paleolitico a Monte Rotondo (Brescia). Nat. Brescia. 15, 45-59.

Coltorti, M., 1980. Segnalazione di manufatti del Paleolitico Inferiore-Medio sulle colline moreniche nei pressi di Carpenedolo (Brescia). Nat. Brescia. 17, 235-241.

Cremaschi, M., 1974. Manufatti del Paleolitico medio-inferiore provenienti da Monte Netto di Brescia e loro rapporti con i depositi quaternari del Colle. Nat. Brescia. 11, 41-57.

Cremaschi, M., 1981. Le attuali conoscenze sul Paleolitico lombardo nel suo contesto paleoambientale. In: Atti del I Convegno Archeologico Regionale, 29 febbraio/1-2 marzo 1980, Cavriana - Brescia, pp. 35-53.

Cremaschi, M., 1987a. Paleosols and vetusols in the central Po Plain (Northern Italy): study. In: Quaternary Geology and Soil Development. Doctoral Thesis, Amsterdam. Edizioni Unicopli, Milano, pp. 306.

Cremaschi, M., 1987b. Loess deposits of the plain of the Po and of the adjoining adriatic basin (northern Italy). In: Pecsi, M., French, H.M. (Eds.), Loess and Periglacial Phenomena. Akademiai Kiado, Budapest, pp. 125-140.

Cremaschi, M., 1990. The loess in northern and Central Italy: a Loess Basin between the Alps and the Mediterranean sea. In: C.N.R. (Ed.), Centro di Studio per la Stratigrafia e Petrografia delle Alpi Centrali, Milano, Italy.

Cremaschi, M., 2004. Late Pleistocene loess. In: Antonioli, F., Vai, G.B. (Eds.), Lithopalaeoenvironmental Maps of Italy during the Last Two Climatic Extremes. Climex Maps Italy e Explanatory Notes, Bologna, pp. 34-37.

Cremaschi, M., Peretto, C., 1977. Il paleolitico dell'Emilia e Romagna. In: Atti XIX Riunione IIPP. IIPP, Firenze, Italy, pp. 15-78.

Cremaschi, M., Peretto, C., 1988. Le paleolitique inferieur de la plaine orientale du Po. L'Anthropologie 92, 643-682.

Cremaschi, M., Alessio, M., Allegri, L., Azzi, C., Calderoni, G., Cortesi, C., Petrone, V., Spezzi, Bottiani, G., 1987. Una data radiocarbonica del paleosuolo su loess incluso nella successione stratigrafica della Val Sorda (sistema morenico del Garda). Rendicont. Soc. Geol. Ital. 10, 29-32.

Cremaschi, M., Fedoroff, N., Guerreschi, A., Huxtable, J., Colombi, N., Castelletti, L. Maspero, A., 1990. Sedimentary and pedological processes in the upper Pleistocene loess of Northern Italy. The Bagaggera sequence. Quat. Int. 5, 23-38.

Cremaschi, M., Di Taranto, E., Maggioni, S., Pavia, F., Peresani, M., 2010. Cava Santa Martina; dati preliminari sul sito e sui materiali rinvenuti in occasione delle attività estrattive presso il comune di Alseno (PC). Poster. XLV Riunione Scientifica IIPP, Modena, pp. 2010.

Cremaschi, M., Rodnight, H., Zerboni, A., Spötl, C., 2011. Loess in Northern Italy. New insights on dating, environment and archaeology. Il Quat. 24, 95-97.

Cremaschi, M., Zerboni, A., Nicosia, C., Negrino, F., Rodnight, H., Spötl, C., 2015. Age, soil-forming processes, and archaeology of the loess deposits at the Apennine margin of the Po Plain (northern Italy). New insights from the Ghiardo area. Quat. Int. 376, $173-188$.

Cremaschi, M., Negrino, F., Magnani, P., Zerboni, A., Nicosia, C., Rodnight, H., Spötl, C., 2016. Il sito Paleolitico di Ghiardo Cave: industrie, cronologia, ambiente. In: Atti della XLV Riunione Scientifica IIPP 'Preistoria e Protostoria dell'Emilia-Romagna', Studi di preistoria e Protostoria 3. Preistoria e Protostoria dell'Emilia Romagna, pp. 49-58.

Delagnes, A., Meignen, L., 2006. Diversity of lithic production systems during the middle paleolithic in France. In: Hovers, E., Kuhn, S. (Eds.), Transitions before the Transition. Evolution and Stability in the Middle Paleolithic and the Middle Stone Age. Springer, pp. 85-107.
Delpiano, D., Heasley, K., Peresani, M., 2018. Assessing Neanderthal land use and lithic raw material management in Discoid technology. J. Anthropol. Sci. 96. https://doi. org/10.4436/JASS.96006.

Delpiano, D., Garbasi, F., 2016. Il Paleolitico del pedeappennino piacentino: analisi delle raccolte di superficie. In: Poster, I Incontro Annuale di Preistoria e Protostoria, 4-5 febbraio 2016, Genova.

Desio, A., 1965. I rilievi isolati della Pianura Lombarda ed i movimenti tettonici del Quaternario. Rendiconti Istituto Lombardo Accademia di Scienze e Lettere, Sezione A 99, 881-894.

Fedele, F., Gagliardi, G., 1988. Ricerche sul giacimento paleolitico del Buco del Piombo, 1975-1978. Quaderni Erbesi 9, 147-166.

Ferraro, F., Terhorst, B., Ottner, F., Cremaschi, M., 2004. Val Sorda: an upper Pleistocene loess-paleosol sequence in northeastern Italy. Rev. Mex. Ciencias Geol. 21 (1), 30-47.

Ferraro, F., 2009. Age, sedimentation, and soil formation in the Val Sorda loess sequence, Northern Italy. Quat. Int. 204, 54-64.

Higham, T., Brock, F., Peresani, M., Broglio, A., Wood, R., Douka, K., 2009. Problems with radiocarbon dating the middle to upper palaeolithic transition in Italy. Quat. Sci. Rev. 28, 1257-1267.

Inizan, M.-L., Reduron-Ballinger, M., Roche, H., Tixier, J., 1995. Technologie de la Pierre Taillée. CREP, Meudon.

Jéquier, C., Peresani, M., Romandini, M., Delpiano, D., Lembo, G., Livraghi, A., LòpezGarcìa, J.-M., Obradovic, M., 2015. The de nadale cave, a single layered Quina Mousterian site in the north of Italy. Quartar 62, 7-21.

Lenzi, F., Nenzioni, G., 1996. Lettere di pietra e I depositi pleistocenici: sedimenti, industrie e faune del margine appenninico bolognese. Editrice Compositori, Bologna, Italy.

Livio, F., Berlusconi, A., Michetti, A.M., Sileo, G., Zerboni, A., Trombino, L., Cremaschi, M., Mueller, K., Vittori, E., Carcano, C., Rogledi, S., 2009. Active Fault-Related Folding in the Epicentral Area of the December 25, 1222 (Io=IX MCS) Brescia Earthquake (Northern Italy): Seismotectonic Implications. Tectonophysics 476. pp. 320-335.

Livio, F., Berlusconi, A., Zerboni, A., Trombino, L., Sileo, G., Michetti, A.M., Spötl, C., Rodnight, H., 2012. Active fold growth constrained by a loess-paleosol sequence (Monte Netto, Southern Alps). Rendiconti Online Societa Geologica Italiana 22, 126-129.

Livio, F.A., Berlusconi, A., Zerboni, A., Trombino, L., Sileo, G., Michetti, A.M., Spötl, C., 2014. Progressive offset and surface deformation along a seismogenic blind thrust in the Po Plain foredeep (Southern Alps, Northern Italy). J. Geophys. Res. - Solid Earth 199 (10), 7701-7721.

López-Garcĺa, J.-M., Luzi, E., Peresani, M., 2017. Middle to Late Pleistocene environmental and climatic reconstruction of the human occurrence at Grotta Maggiore di San Bernardino (Vicenza, Italy) through the small-mammal assemblage. Quat. Sci. Rev. 168, 42-54.

Martini, M., Sibilia, E., Croci, S., Cremaschi, M., 2001. Thermoluminescence (TL) dating of burnt flints: problems, perspectives and some examples of application. J. Cult. Herit. 2, 179-190.

Monegato, G., Scardia, G., Hajdas, I., Rizzini, F., Piccin, A., 2017. The Alpine LGM in the boreal ice-sheets game. Sci. Rep. 7, 2078.

Peresani, M., 2011. At the end of Middle Palaeolithic in the Italian Alps. An overview on Neandertal land-use, subsistence and technology. In: Conard, N.J., Richter, J. (Eds.), Neanderthal Lifeways, Subsistence and Technology. Vertebrate Paleobiology and Paleoanthropology Series. Springer, pp. 249-259.

Peresani, M., 2012. Fifty thousand years of flint knapping and tool shaping across the Mousterian and Uluzzian sequence of Fumane cave. In: In: Carbonnell, E., Chacon, G.M., Vaquero, M. (Eds.), The Neanderthal Home: Spatial and Social Behaviours, vol 247. Quaternary International, pp. 125-150.

Peresani, M., Cremaschi, M., Ferraro, F., Falgueres, C., Bahain, J.-J., Gruppioni, G., Sibilia, E., Quarta, G., Calcagnile, L., Dolo, J.-M., 2008. Age of the final middle palaeolithic and uluzzian levels at Fumane cave, northern Italy, using 14C, ESR, 234U/ 230Th and thermoluminescence methods. J. Archaeol. Sci. 35, 2986-2996.

Peresani, M., Nicosia, C., 2015. Comparative Study of Two Late Pleistocene Sequences with Paleosols and Aeolian Deposits at the Alpine Foreland. Geografia Fisica e Dinamica Quaternaria.

Peresani, M., Centi, L., Di Taranto, E., 2013. Blades, bladelets and flakes: a case of variability in tool design at the dawn of the Middle-Upper Palaeolithic transition in Italy. Comptes Rendus Palevol 12 (4), 212-221.

Peresani, M., Boldrin, M., Pasetti, P., 2015. Assessing the exploitation of double patinated artifacts during the Late Mousterian. Implications for lithic economy and human mobility in the North of Italy. Quat. Int. 361, 238-250.

Peresani, M., Delpiano, D., Duches, R., Gennai, J., Marcazzan, D., Nannini, N., Romandini, M., Aleo, A., Cocilova, A., 2017. Il Musteriano delle unità A10 e A11 a Grotta di Fumane (VR). Risultati delle campagne di scavo 2014 e 2016. FOLD\&R (Fasti On Line Documenti \& Ricerche.

Peresani, M., Romandini, M., Duches, R., Jéquier, C., Nannini, N., Pastoors, A., Picin, A., Schmidt, I., Vaquero, M., Weniger, G.-C., 2014. New evidence for the Mousterian and gravettian at rio secco cave, Italy. J. Field Archaeol. 39 (4), 401-416.

Peretto, C., 1990. Late Early and Middle Paleolithic assemblages: technical, typological and chronological aspects of the lithic complexes in the Po plain and in the Marche province. In: Cremaschi, M. (Ed.), The loess in Northern and Central Italy: a loess basin between the Alps and the Mediterranean Sea. C.N.R., Centro di Studio per la Stratigrafia e Petrografia delle Alpi Centrale, Milano, Italy, pp. 151-166.

Pini, R., Ravazzi, C., Donegana, M., 2009. Pollen stratigraphy, vegetation and climate history of the last $215 \mathrm{ka}$ in the Azzano Decimo core (plain of Friuli, north-eastern Italy). Quat. Sci. Rev. 28, 1268-1290.

Pini, R., Ravazzi, C., Reimer, P.J., 2010. The vegetation and climate history of the last glacial cycle in a new pollen record from Lake Fimon (southern Alpine foreland, N- 
Italy). Quat. Sci. Rev. 29, 3115-3137.

Ravazzi, C., Deaddis, M., De Amicis, M., Marchetti, M., Vezzoli, G., Zanchi, A., 2012. The last 40 ka evolution of the Central Po Plain between the Adda and Serio rivers. Géomorphologie 18 (2), 131-154.

Venzo, S., 1957. Rilevamento geologico dell'Anfiteatro morenico del Garda dal Chiese all'Adige. Parte I: tratto occidentale da Gardone a Desenzano. Memorie della Società Italiana di Scienze Naturali, Milano XlV, I.

Venzo, S., 1961. Rilevamento geologico dell'anfiteatro morenico del Garda. Parte II: tratto orientale Garda-Adige e anfiteatro atesino di Rivoli Veronese. Memorie della Società Italianadi Scienze Naturali, Milano XIII (1), 1-64.
Zerboni, A., Trombino, L., Frigerio, C., Livio, F., Berlusconi, A., Michetti, A.M., Rodnight, H., Spötl, C., 2015. The loess-paleosol sequence at Monte Netto: a record of climate change in the Upper Pleistocene of the central Po Plain, northern Italy. J. Soils Sediments 15 (6), 1329-1350.

Zerboni, A., Amit, R., Baroni, C., Coltorti, M., Ferrario, M.F., Fioraso, G., Forno, M.G., Frigerio, C., Gianotti, F., Irace, A., Livio, F., Mariani, G.S., Michetti, A.M., Monegato, G., Mozzi, P., Orombelli, G., Perego, A., Porat, N., Rellini, I., Trombino, L., Cremaschi, M., 2018. Towards a map of the Upper Pleistocene loess of the Po Plain Loess Basin (Northern Italy). Alpine Mediterr. Quat 31, 253-256. 